IJMS 18 (Special Issue), 59-72 (2011)

\title{
HARMONIZING THE TENTH MALAYSIA PLAN PRIORITIES WITH THE NEW ECONOMIC MODEL AND THE GREEN WORLD ORDER
}

\author{
SALEEM MUSTAFA \\ Borneo Marine Research Institute \\ Universiti Malaysia Sabah \\ SHAHBUDIN SAAD \\ Institute of Oceanography \& Maritime Studies \\ International Islamic University Malaysia, Pahang
}

\begin{abstract}
The New Economic Model (NEM) is a need-based concept intended to integrate innovative ideas in chartering the path of socio-economic development of Malaysia. NEM is timely for building resilience into the economic systems through the participation of all, and for the benefit of all sections of the society. In a high income society, there will have to be value for money and money for value, reduction in subsidies, efficient fiscal management to reduce unnecessary expenditure, management of value-added and market-driven products and services, revamping of the education system, reviewing of RED priorities, enhancing staff efficiency, less discussion for more action, less paper work for more output, and realistic targets for delivery. The sustainability dimension of NEM should envisage sustainable management of natural resources. This is achievable by aligning our activities with the new concept of 'Green World Order' which expands the existing peace and stability mottos of the World Order to include environment and sustainability. Under this concept there is a need for making changes in our activities. For example, short-term economic gains at the expense of long-term benefits that produce footprints of irreversible damage have to be addressed. Our development planning requires resetting in the light of environmental limitations to achieve the goals of NEM. With the valuation of the ecosystem services becoming increasingly important, we should pursue this matter aggressively to seek best deals for the natural resources we are blessed with. We can claim a substantial amount of international climate change mitigation funds because some of our resources (forests, mangroves and coral reefs) are carbon sinks which international agencies are seeking for investment. This not only generates resources for conservation but also brings dividends to the custodians of the carbon sinks.
\end{abstract}


With an effective action plan, Malaysia can take advantage of the growing carbon market and green economy. The main elements of the proposed action plan are discussed in this paper.

Keywords: Development plan, green perspectives, economic model.

\section{Introduction}

The New Economic Model (NEM) is a need-based concept intended to integrate innovative ideas in chartering the path of socio-economic development of Malaysia under the changing global environment. The three main elements of this model, namely high income, sustainability and inclusiveness are logical outcomes of the economic transformation which will also provide a yardstick to measure the success of the directions of the new policy.

NEM is timely since the economic meltdown witnessed in recent years in the world's leading economies has exposed the vulnerability of contemporary systems of economic governance, and calls for innovative approaches. In this paper, the focus will be mainly on the environmental dimension of NEM.

In a high-income society, there will have to be 'value for money' and 'money for value', reduction of subsidies, efficient fiscal management that reduces unnecessary expenditure, generation of value-added and market-driven products and services, revamping of the education system, reviewing of $R \& D$ priorities, elaborate mechanisms for improving staff efficiency, less discussion-oriented meetings and more action, less paper work and more output, realistic targets to achieve results, and a rational time-management system for delivery. This is achievable by a knowledge-based approach that envisages a kind of research culture for providing reasonable tools for policy-formation whether for introducing a new education policy or action plans for national development, including those for human resources, efficient management of time for delivery of duties effectively and efficiently, and mechanisms which are developed for accurate assessment of the quality of delivery and fixing accountability. Certainly, we need innovative approaches, not those which have become obsolete. A rational explanation of the relevance of education and knowledge in policy formation and implementation is available in the work of Hill and Saleem (2011).

Any economic model to be successful should include sustainable management of natural resources (or 'natural capital'). No country can sustain its economy without sustaining the natural resources. In 
a world facing the greatest challenge of the $21^{\text {st }}$ century in the form of climate change, it is absolutely necessary to consider environment in development planning. In other words, we have to align with the emerging concept of the 'Green World Order'. We know that the World Order is a system for regulating world events, especially for peace, stability and security. The concept of Green World Order is rooted in the environment and applies to one and all since we all live in one large global environment (Saleem, 2011). It is an extension of the peace and stability mottos of the World Order by including environment and sustainability.

There are various dimensions of sustainability which have been reviewed by Hill (2011) while trying to emphasize that sustaining humanity in the $21^{\text {st }}$ century depends on sustaining the environmental resources in a way that the consumption does not exceed the rate of regeneration. Ironically, humanity is demanding greater economic productivity when resources that feed productivity are depleting. According to Weizsacker (2011) the extraction of resources increased by $50 \%$, from 40 billion tones to 58 billion tones in just 25 years between 1980 and 2005, and this is likely to increase further to a staggering 100 billion tones by 2030 . The author believes that scientific, economic and social research can contribute to the measurement of the consumption rate, the level of efficiency, development of more efficient processes and technologies, and innovative approaches which can provide a model of an appropriate economic system. Without major new policies, population expansion and economic growth will push natural resources to their limits by 2030 (OECD, 2010). This report also calls for a concerted action to promote the efficient use of resources.

\section{The Sustainability Concerns}

Since the focus of this paper is on environmental resources, the term sustainability here denotes "Development of systems capable of ensuring that future generations will have coupled humanenvironment systems capable of providing goods and services for the long-run, without degradation in structure or function" (IGBP, 2008). As an example, if economic growth is based on the conversion of forest for agriculture, timber, livestock ranching and fuel crops, this will not provide conditions for a sustainable economic development. In such situations, the short-term economic gains are at the expense of long-term benefits, and they leave behind footprints of irreversible damage. The solution lies not in developing new technology isolated 
from environmental concerns but in investing in existing knowledge to invent new methods of benefiting from the resources of nature, promoting ecological agriculture, ecological fisheries, ecological aquaculture and alternative energy resources, and of course, translation of knowledge into products and services through efficient ecosystem management. Development that depletes and degrades environmental resources is unsustainable (Saleem \& Shahbudin, 2011). The authors are of the view that we need to reset our development planning and aspirations in the light of environmental limitations to achieve the goals. Their logic is simple - the climate is changing the world we live in, so how can we go about doing what we have always done. Certainly, we need to change with time and adapt to climate change since without adaptation the adverse effects of climate change will be severe.

This issue of sustainability of natural resources was discussed recently by Hill and Saleem (2011). A Strategic Thrust area of the Tenth Malaysia Plan 'The Sustainability of the Environment is Our Responsibility' deals exclusively with this matter. It explains the measures to be implemented to ensure the sustainability of environmental resources. This concept has been further defined to emphasize that environmental conservation cannot depend entirely on a sense of responsibility but economic opportunities will have to be developed to create value from conservation. Thus, eco-tourism has been identified as an activity that can generate income through the conservation of the biodiversity of flora and fauna. The strategic thrust encourages industrial participation by way of incentives provided by the government through the Green Technology Financing Scheme worth RM1.5 billion to enhance the deployment of green technology in the production of goods and services. Even environment-friendly housing is included in the Plan aiming at new-design buildings that meet green standards.

Faizan (2011) underlined the resistance and challenges when it comes to changing human practices and lifestyles but highlighted the lack of options in a changing environment. He has advocated innovative approaches towards the transformation of our conventional economics that deals with the production, distribution and consumption of goods and services, and their management into a subject which despite being rooted in economics also promotes harmonious integration of human needs and nature. It makes sense to understand that sustainable living is about lifestyles that reduce our use of Earth's natural resources. Human activities should be in natural balance and be respectful of the fact that our relationship should be symbiotic with the natural ecology and cycles of the planet for a sustainable living (CELL, 2010). It is 
time that our economic decisions are linked to ecosystem resilience. The value of the world's ecosystem is enormous. The economic value of 17 ecosystem services for the entire biosphere is estimated to be US\$33 trillion $\left(10^{12}\right)$ per year (Costanza et al., 1997). With such a value tag, how can these ecosystems be ignored in economic planning?

Some reports which are yet to be authenticated suggest that a capital fund to be generated by carbon taxes in industrialized countries will amount to some US\$45 trillion and this will be made available for managing the carbon sinks and other requirements of the global environmental governance.

\section{Brown Economic Model versus Green Economic Model}

There is some apprehension about economic slowdown resulting from adopting the green economy and all the other green concepts under the heat of the moment of heightened concern about climate change. With rational thinking and analysis of the unfolding scenario, it is hard to accept such viewpoints. The environment is in a serious crisis and our economic systems depend on environmental resources, so how can we expect economy to grow without environmental mitigation? Furthermore, the climate change clock cannot be put back, so it is not under the heat of the moment that it will dissipate. It is a moment of truth, howsoever inconvenient it might be. It is something we have to accept and learn to live with by adapting to the green perspectives for the sustainability of our economy, and in fact, for the sake of our existence.

The latest UN report explicitly states that by following the green economy approaches, sustainable benefits will accrue to the environment, economy and society. It will increase the natural capital such as forests, fisheries and water resources, all of which have been severely depleted as a consequence of the current 'Brown Economic Model' which lays emphasis on economic growth over natural resources development (UNEP, 2011). A comprehensive analysis of the link between natural resources management and food security in the context of sustainable development has been presented by Hill and Saleem (2011).

There is, however, a need for a cautious approach and knowledgebased decisions coupled with realism. When economic systems undergo transformation, there could be hardships. Transformation of the Brown Economic Model into the Green Economic Model 
will also entail sluggish growth initially and if we are resilient and consistent, then this transition period of transformation will give way to prosperity. The duration of transition will depend on the approaches and initiatives, ground realities and cooperation of the society. Perhaps, in a carefully planned transformation based on strong fundamentals, one could see tangible gains in terms of natural resources replenishment, poverty alleviation and better means of livelihoods of the impoverished communities among others.

The main sectors identified by UN agencies on environment for a future green economy are: forestry, fisheries, water, tourism, agriculture, industry, waste and transport. An investment of US\$1.3 trillion which amounts to $2 \%$ of the world GDP is being mooted for green actions with good job prospects. The UNEP (2011) report comprises the following recommendations that will provide conditions for the transition of brown economy to green economy:

1. Establish a regulatory framework that limits unsustainable use and management practices; set clear guidelines for promoting green models and initiatives in business, industries and markets; and remove obstacles to green development by setting standards, regulations and targets.

2. Focus government spending, investment and subsidies on measures that promote the greening of the economy.

3. Phase out government subsidies that support the unsustainable depletion of natural resources or the degradation of ecosystems.

4. Encourage green investment and sustainable consumption patterns through tax incentives and market-based instruments (e.g. carbon trading schemes).

5. Build capacity and skills in all countries by training and educating the workforce. In poorer nations, technical and financial help would be needed to strengthen government institutions and to train workers by providing them with the essential knowledge, the technical skills needed for the green economy, and its management.

6. Enhance global governance structures, through, for example, multilateral environmental agreements, or using international trade to promote the trade of green goods and services.

The private sector should have a major responsibility in greening the economy. The government has allowed it to operate under liberal regulatory mechanisms. Their activities have a major contribution to the carbon footprint. The decision-making process and its 
implementation are more rapid in the private sector. They should develop a regulatory mechanism to help in the transformation to green economy which will produce quick results.

In a policy declaration from the Global Science and Innovation Advisory Council (GSIAC) for Malaysia hosted by the New York Academy of Sciences, the Malaysian government resolved to bring in innovative science and technology initiatives related to the environment to build on existing national development programmes, including the NEM, the Government Transformation Programme (GTP) and the Economic Transformation Programme (ETP). The details are contained in the 17 May 2011 report released by the New York Academy of Sciences.

\section{Malaysia's Advantages}

As far as Malaysia is concerned, we are blessed with tropical rainforests, mangroves, seagrasses and coral reefs that provide us an enormous capital to generate sustainable income through wise management. Our biological resources are excellent natural 'carbon sinks' (environmental reservoirs such as oceans and forests that absorb large quantities of $\mathrm{CO} 2$ from the atmosphere) which international agencies are seeking to invest cash flows from industrialized nations.

Malaysia's coastline measures 4,809 km (Peninsular Malaysia $=1,972$ $\mathrm{km}$; Sabah $=1,802 \mathrm{~km}$; Sarawak $=1,035 \mathrm{~km}$ ).

With the proclamation of 200 nautical miles ( $320 \mathrm{~km}$ ) of EEZ in 1980, Malaysia gained $138,700 \mathrm{~km}^{2}$ of sea area resulting in a total marine area of $332,673 \mathrm{~km}^{2}$ which is slightly larger than the land area $(329,847$ $\mathrm{km}^{2}$ ) (Mohamed et al., 1991).

Malaysia has the advantage of being located in a geographical region which is relatively safe from natural hazards unlike countries in the 'rim of fire' in south-east Asia or those exposed to the vagaries of strong seismic activity, typhoons and tornadoes in the far-east and elsewhere. We have a strategic location in the 'Coral Triangle' region which is rich in marine biodiversity and carbon sequestration resources.

The forest area of Malaysia is 19.42 million hectares (more than $59 \%$ of its land area which measures 32.9 million hectares) with 5.88 million hectares of forest in Peninsular Malaysia, 4.30 million hectares 
in Sabah and 9.24 hectares in Sarawak (MTC, 2007). Malaysia has 640,000 hectares of mangroves which can sequester about 1 million $t$ C $\mathrm{yr}^{-1}$ (Ong \& Gong, 2004).

The country has sufficient rainfall, measuring an annual average of $250 \mathrm{~cm}$ which can bring investment in water-harvesting and recharge.

With the natural resources depleting and crossing the threshold limits, and the global environment worsening due to climate change, the world has to move fast in taking action to save what is left. Malaysia's tropical rainforests and mangroves are 'green lungs' for the whole planet and the world will be willing to invest in saving these treasures to be able to breathe clear air and mitigate the effects of climate change. Malaysia cannot do it all by itself without economic impacts and social implications, and if our resources are to play a global environmental role, we deserve global investment. The environment has been brought to this state by about less than two centuries of industrialization. It has made industrialized countries rich, powerful and affluent but at the cost of the environment. Developing countries, while short of cash and materialistic affluence, are rich in carbon sink resources and they should be absolutely committed to protecting them but at the same time they should receive a fair share of funds allocated for the conservation of the global environment. Some reports suggest that the capital fund to be generated by carbon taxes in industrialized countries will amount to some US\$45 trillion and this will be made available for managing the carbon sinks and other requirements of the global environmental governance. If that is indeed true, we need to see cash flows for the conservation of natural resources and effective action.

Developing countries should have a voice in the system of global environmental governance and they should be in a position to resist the imposition of any unfair regime that will ensure continued environmental degradation by industrialized countries and the buffering of its impact by developing countries with no mitigation for their suffering. It will not serve the peace and stability pillars of the World Order without the remaining two pillars (environment and sustainability) that collectively form the foundation of the Green World Order. Industrialized countries should not be telling the developing countries to learn to live happily in poverty by disengaging from materialistic pleasures that they enjoy and which have significantly contributed to climate change. We find logic in the views of Nobel Prize-winning Physicist, Dr. P.M.S. Blackett that "It is the arrogance of the rich to teach the virtue of poverty to the poor". 
We should have a clear idea of the fundamental pillars of the Green World Order to be able to position Malaysia as a strategic partner in the world environmental organization without compromising its national interest in the legal power structure that will be inherent in such an organization.

Achieving a high income and sustaining it in a changing global environment poses unprecedented challenges which can only be addressed by a comprehensive action plan and aggressive campaign to seek world attention.

\section{Managing Carbon Sinks}

The importance of managing natural carbon sinks cannot be overstated. We must move fast in this area to ensure the flow of investment in our nature conservation programmes and support sustainable economic development. The world wants to breathe clean air and it will look at us to provide it. It is a win-win situation. In addition to forests, the coastal habitats such as mangroves and seagrasses are also significant carbon sinks. Their carbon management capacity has not received the attention that it deserves. They can be a basis for 'save-and-earn' programmes contributing to safeguarding food security and supporting livelihood of the coastal communities. Malaysia has the resources for offsetting the emissions of gases like $\mathrm{CO} 2$ (Brown Carbon) and soot (Black Carbon), and storing the emitted carbon in the terrestrial vegetation, mainly the tropical rainforests (Green Carbon) and in the oceans (Blue Carbon). Rehabilitating and managing the blue carbon sinks (mangroves and sea grasses) for carbon sequestration will bring investment, transform the projects as self-sustaining in the long-run and contribute a great deal to climate change adaptations.

Forests and oceans are sources of livelihood for tens of millions of people around the world. By absorbing carbon dioxide from the atmosphere, we contribute to stabilizing greenhouse gas concentrations and improving the quality of the air that we breathe. With our rich tropical rainforests, mangroves and the sea grasses, we should not lose out in seeking international investment through carbon sequestration projects and carbon trade. Many countries are taking carbon trading seriously and some have started the sale and purchase of carbon credits. We have to start working towards this system to take advantage of the impending carbon economy. Carbon trading institutionalizes a mechanism of reducing the carbon footprint 
(total amount of greenhouse gases produced directly or indirectly by human activities in a given time frame). The essential purpose of carbon trading is to offset carbon emissions from one activity (such as burning of fossil fuel to produce electricity) with another that offsets it (reforestation). Under this system, the producers of excess emissions are required to trade with producers of reduced emissions. It is not as easy as it sounds since the nature of activities that produce emissions and the efficiency of neutralizing them have to be examined. We need to apply measures for adding value to our carbon sequestration resources by way of their rehabilitation and restoration to build their ecological resilience, and organized carbon farming. This will combat climate change effects and threat to coastal zone security that such effects entail.

Investment in environmental conservation is a sort of Foreign Direct Investment (or FDI) but it should be free from foreign direct interference which IMF and World Bank loans often envisage, and which have strings that affect a recipient country's system of governance. The issue here is qualitatively different. The world needs to breathe clean air and live on environmental resources, protected from disasters and food insecurity; and the carbon sink resources provide the means to help the world. We should be in a position to maintain our own timetested systems of governance which have ensured stability, social justice and development. We should remain masters of our destiny and custodians of our resources. With the environmental problems getting worse by the day, the world will probably see less of political interference and more of environmental activism and monitoring by major contributors to the carbon sink fund. We have to have a high level of readiness to protect our interest in this kind of Green World Order.

In addition to bringing international investment the spin-off effects of strengthening these 'green lungs' will be immense since many of our ecosystems are vitally important for biodiversity, food security and adaptation to the effects of climate change by way of mitigating the adverse effects of extreme weather conditions. This will save enormous economic burden of natural hazards.

The socioeconomic conditions of coastal communities depend on the ecosystem health and if environment degrades by short-sighted policies, poverty will aggravate, not alleviate. NEM will be able to deliver its high income objective when ecosystems thrive. An 
immediate gain will be its biodiversity value. For example, biodiversity will become the basis for bioprospecting that in turn will support a biotechnology industry for the generation of high-value products for pharmaceutical, nutraceutical and cosmetic formulations. The growing nature-tourism industry also depends on biodiversity.

Food security is paramount in any economic system. According to the Food and Agriculture Organization, it is achieved when 'all people, at all times, have physical and economic access to sufficient, safe and nutritious food to meet their dietary needs and food preferences for an active and healthy life'. Food is a product of environment. A degraded environment causes food insecurity. Environmental change will affect food production, livelihood and economies (Ericksen, 2008). It is better to understand that livelihood here refers to "capabilities, assets (including both material and social resources) and activities required for a means of living. A livelihood is sustainable when it can cope with and recover from stresses and shocks, and maintains or enhances its capabilities and assets both now and in the future, while not undermining the natural resource base". It is a definition proposed by IGBP (2008) and widely accepted. In an earlier publication, Saleem (2010) presented an elaborate account of the seafood security in a changing climate.

We have to be knowledgeable in dealing with the international institutions and for this purpose we need to develop human resources and experts to handle such complicated matters.

Inclusiveness of NEM is a visionary idea since it seeks participation of all sections of the society, but is also open to all ideas related to economic growth. In a country that prides itself with both cultural diversity and biodiversity, such an inclusive approach to socioeconomic development is important. In Malaysia, especially Sabah, the biodiversity and diversity of human cultures and traditions are intricately related and NEM works for the betterment of both. While working on human interaction with the natural resources of Amazon, Nobre Lahsen and Ometto. (2008) concluded that cultural diversity and biological diversity are interdependent and that the former supports the latter. They suggested the need for giving due consideration to local and social realities while planning and executing development strategies. The element of inclusiveness in NEM is therefore realistic and relevant to Malaysia. 
IJMS 18 (Special Issue), 59-72 (2011)

\section{Action Plan}

To be able to actively contribute to climate change mitigation and get the maximum possible benefits from carbon trade and green economics, we should take the necessary measures as described below:

1. Evaluating carbon sequestration resources.

2. Resolving carbon sequestration and biodiversity related issues.

3. Making accurate inventories of natural carbon sinks.

4. Providing effective governance for conservation and rehabilitation of carbon sinks.

5. Adopting verifiable methods of measuring carbon sinks consistent with international standards.

6. Developing human resources in environmental economics and management.

7. Developing a comprehensive document for seeking carbon funds from the World Bank and other global institutions.

8. Including resource valuation, carbon sink and green technology in high priority and top down R \& D programmes.

9. Researching enforcement problems and effective solutions.

10. Collaborating internationally in carbon sinks.

11. Developing a political consensus for supporting a carbon trading framework.

12. Framing environmental laws to deal with the new issues.

13. Resolving the problems of access and benefit-sharing, especially pertaining to carbon sequestration resources on private land.

14. Greening of educational curricula.

15. Setting up a Study Group or an autonomous centre (Centre for Climate Change Mitigation Studies/ Centre for Carbon Management Studies/ other suitable names) with a clearly defined mandate to address all the pertinent issues related to this matter.

\section{Conclusion}

The $10^{\text {th }}$ Malaysia Plan has come at a time when the world is facing the biggest challenge of the $21^{\text {st }}$ century - the climate change. Certainly, environment should be central to our development planning to put the society on sustainable pathways. We just cannot afford to lose out in a carbon market that is rapidly growing and is expected to run into trillions of dollars. With the biological heritage of carbon sink resources that Malaysia is bestowed with, our active participation in the climate change mitigation fund is of national interest. In an 
increasingly interdependent world which is also facing the heat of a powerful force in the form of global warming, an adaptive adjustment of national socio-economic development plans vis-a-vis the dynamics of global financial scenarios is necessary, especially for a trading nation such as Malaysia. We will stand to gain with the right policies and knowledgeable human resources. We will stand to lose without proactive planning and preparedness for an impending situation. The $10^{\text {th }}$ Malaysia Plan is visionary and provides a broad framework for micromanagement and microadjustment of the plan components within the policy framework. We suggest setting up a study group centre at the national level to address all the pertinent issues related to carbon sequestration and prepare a blueprint for preparing the nation for carbon economy for the consideration of the policy makers. At the same time, we need to implement the government's concept of 'Smart City-Smart-Village' for selected areas and demonstrate that it achieves its aims and objectives.

\section{References}

CELL. (2010). Center for ecological living and learning philosophy. Change Newsletter, 71, 10-16.

Costanza, R., d'Arge, R., de Groot, R., Farber, S., Grasso, M., Hannon, B., Limburg, K., Naeem, S., O'Neill, R.V., Paruelo, J., Raskin, R.G., Sutton, P., \& van den Belt, M. (1997). The value of the world's ecosystem services and natural capital. Nature, 387,253260.

Ericksen, P. (2008). Global environmental change and food security. Global Change, 71(10), 15-16.

Faizan, H. (2011). Green economics and green business management. In Green world order: Delaying the doom in a changing climate (pp. 40-61). Koln, Germany: Lambert Academic Publishing.

Hill, J. (2011a). Education for sustainable living. In Green world order: Delaying the doom in a changing climate (pp. 62-83). Koln, Germany: Lambert Academic Publishing.

Hill, J. (2011b). Sustainable community development emerges from sustainable natural resource management. In Green world order: Delaying the doom in a changing climate (pp. 84-101). Koln, Germany: Lambert Academic Publishing.

Hill, J., \& Saleem, M. (2011). A curriculum framework for a tertiary sustainability course. ChemEd New Zealand, 124, 12-22.

Hill, J., \& Saleem, M. (2011). Natural resources management and food security in the context of sustainable development. Sains Malaysiana, 40, 1311-1340. 
IJMS 18 (Special Issue), 59-72 (2011)

IGBP. (2008). Sustainable livelihoods in a changing earth system. Global Change, 71, 14.

Mohamed, M. I. H., Low, A. T., Mohsin, A. K. M., \& Said, M. Z. M. (1991). Findings of studies of the offshore waters of the Malaysian EEZ. In B. H. R. Othman, N. M. Mahadi, A. B. Jaafar, \& S. L. Tang, (Eds.), The marine environment challenges and opportunities (pp. 103-119). Volume 2: Ocean Studies \& Management (ENSEARCH, Petaling Jaya).

MTC. (2007). Malaysia: Sustainable forest management. Kuala Lumpur: Malaysian Timber Council.

Nobre, C., Lahsen, M., \& Ometto, J. (2008). A scientific and technological revolution for the Amazon. Global Change Newsletter, 71, 7-9.

OECD. (2010). Eco-innovation in industry. Enabling green growth. France: OECD Publishing.

Ong, J. E., \& Gong, W. K. (2004). Mangroves as sinks for atmospheric carbon. In P.S. Moi, C.V. Ching, H.S. Chye, N. Mokhtar, \& J.O.L. Sim, (Eds.), Marine science into the new millennium: New perspectives and challenges (pp. 17-22). UMMReC, Kuala Lumpur.

Saleem, M., \& Shahbudin, S. (2011). Ecosystem functioning: Thresholds and challenges. In M. Saleem, \& J. Hill (Eds.), Green world order: Delaying the doom in a changing climate (pp. 6-19). Koln, Germany: Lambert Academic Publishing.

Saleem, M. (2010). Seafood security in a changing climate: Adapting fisheries $\mathcal{E}$ aquaculture for sustainable production. Koln, Germany: Lambert Academic Publishing.

Saleem, M. (2011). Introduction. In M. Saleem, \& J. Hill (Eds.), Green world order: Delaying the doom in a changing climate. Koln, Germany: Lambert Academic Publishing.

UNEP. (2011). Towards a green economy: Pathways to sustainable development and poverty eradication. United Nations Environment Program, Nairobi.

Weizsacker, E.U.V. (2011). Think big for a resource efficient future. Science for Environment Policy, report number 261. 